\title{
PENGEMBANGAN MODEL PELATIHAN ONLINE BERBASIS WEB UNTUK KEUNGGULAN BERSAING PADA PT INTELLISYS TRIPRATAMA
}

\author{
Thomas Ivantoro Prasetyo; Gintoro \\ Jurusan Sistem Informasi, Fakultas Ilmu Komputer, Bina Nusantara University \\ Jln. KH Syahdan No 9, Kemanggisan, Palmerah, Jakarta Barat 11480 \\ gintoro@binus.edu
}

\begin{abstract}
In order to face competition, PT Intellisys, as the service provided in web-based online training, is trying to serve every customer from wherever and whenever in a good quality service. It started with the analysis of competitior's condition using Porter's five competitive forces analysis, internal condition using SWOT analysis, and internal componay process using Value Chain analysis to conclude a suitable IT strategy for the company. It is then continued with Work-Centered analysis to produce the increasing of business process then designing web-based online training system model in doing evaluation to show good accommodation and training service from Intellisys to customers that could bring the company competitive advantages. The research result is a model design from web-based online training system that is cheap and flexible, easier to get wherever and whenever, and also innovative and easier-to-learn material.
\end{abstract}

Keywords: e-learning, competitive advantages, information technology, training service provider, SCROM

\section{ABSTRAK}

Dalam rangka menghadapi persaingan, PT Intellisys, sebagai penyedia layanan pelatihan online berbasis web, berusaha untuk dapat melayani semua pelanggan dari mana saja dan kapan saja dengan kualitas pelatihan yang terbaik. Dimulai dengan analisis kondisi persaingan perusahaan menggunakan analisa Porter's Five Competitive Forces, kondisi internal dengan analisa SWOT dan internal proses perusahaan dengan analisa Value Chain untuk dapat dirumuskan strategi IT yang cocok untuk perusahaan. Dilanjutkan dengan analisis Work-Centered untuk menghasilkan peningkatan proses bisnis kemudian merancang model sistem pelatihan online berbasis web menggunakan Object-Oriented Analysis and Design. Pada tahap terakhir dilakukan evaluasi yang menunjukkan kemudahan-kemudahan dan layanan pelatihan yang baik yang dapat diberikan oleh Intellisys kepada pelanggan dan dapat memberikan keunggulan bersaing bagi Intellisys. Hasil dari penelitian ini adalah rancangan model dari sistem pelatihan online berbasis web yang murah dan fleksibel, mudah didapatkan dimana saja dan kapan saja, serta materi yang inovatif dan mudah dipelajari.

Kata kunci: e-learning, keunggulan bersaing, teknologi informasi, penyedia layanan pelatihan, SCORM

\section{PENDAHULUAN}

Pada masa perkembangan bisnis yang sangat cepat seperti saat ini, perusahaan berusaha dengan berbagai macam cara untuk meningkatkan keuntungan bisnis. Teknologi informasi dapat membantu perusahan untuk mengambil keputusan yang lebih baik, respon yang cepat pada bisnis, meningkatkan komunikasi, serta melakukan investasi dengan cermat.

PT Intellisys Tripratama adalah sebuah perusahaan skala menengah yang menyediakan jasa pelatihan, konsultasi dan jasa pengembangan solusi perangkat lunak yang sudah berdiri sejak tahun 1996. Intellisys mempunyai misi untuk menjadi mitra utama dalam bidang teknologi informasi bagi perusahaan mitranya, untuk mewujudkan keuntungan bisnis dengan meningkatkan efektivitas perusahaan.

Untuk mewujudkan misinya tersebut, Intellisys menyediakan tenaga ahli yang bersertifikasi untuk produkproduk teknologi informasi yang cukup terkenal seperti Microsoft dan Oracle. Dengan tenaga ahli ini diharapkan dapat memberikan pelayanan yang baik dan memuaskan pelanggannya melalui berbagai layanan yang disediakan seperti pelatihan, konsultasi dan jasa pengembangan solusi perangkat lunak. Profesionalitas tenaga ahli dan pelayanan dari Intellisys menjadikan perusahaan ini menjadi salah satu
Gold Partner perusahan teknologi informasi terbesar di dunia yaitu Microsoft Corporation. Intellisys memegang beberapa jenis kompetensi yaitu Microsoft Learning Solutions, Custom Development Solutions, Data Management Solutions, Advanced Infrastructure Solutions.

Persaingan kualitas dan harga semakin kompetitif pada dunia IT, terutama pada industri pelatihan teknologi informasi. Ditambah adanya krisis global yang membuat bisnis perusahaan pelanggan menjadi lesu, menjadikan anggaran yang dikeluarkan untuk investasi IT semakin berkurang.

Karena jumlah customer menjadi lebih sedikit daripada penawaran yang ada dari banyak penyedia jasa, menjadikan pelanggan memiliki bargaining power yang kuat untuk menentukan mana penyedia jasa yang mau digunakan. Pelanggan meminta pelayanan dengan kualitas yang bagus dan murah. Tentu saja hal ini sangat dirasakan oleh Intellisys sebagai perusahaan penyedia jasa pelatihan teknologi informasi. Beberapa hal tersebut menyebabkan permintaan untuk jasa pelayanan pelatihan teknologi informasi yang ditawarkan oleh Intellisys menjadi menurun. Menyadari keadaan seperti ini, Intellisys segera mengambil manuver untuk melakukan diferensiasi pada layanan pelatihan teknologi informasi dengan membuat suatu bentuk layanan pelatihan baru yang murah dan berkualitas. 
Memanfaatkan keunggulan teknologi informasi yang ada, Intellisys berkomitmen untuk membuat solusi jenis layanan pelatihan baru dengan konsep e-Learning. Konsep ini sangat tepat untuk memberikan suatu jenis layanan yang menyediakan kebutuhan akan informasi pembelajaran teknologi informasi yang murah, dengan materi yang mudah didapatkan, inovatif dan ditambah adanya kelas virtual di mana trainer bisa berinteraksi secara online dengan peserta pelatihan seperti layaknya pelatihan konvensional.

Dengan konsep e-Learning ini diharapkan akan menghemat biaya akomodasi yang dikeluarkan oleh pelanggan untuk mendapatkan jasa layanan pelatihan teknologi informasi. Pelanggan dimudahkan dengan tidak perlu mengeluarkan biaya dan waktu yang besar untuk mencapai lokasi tempat pelatihan, terutama pelanggan dari luar kota. Layanan pembelajaran online ini tidak terbatas pada waktu dan ruang karena bisa diperoleh dimanapun hanya dengan mengakses melalui internet. Intellisys dapat memperluas jangkauan pasar ke daerah yang belum terjangkau oleh kompetitor lainnya.

Jasa layanan pelatihan online dengan konsep e-Learning juga memudahkan Intellisys dengan tidak perlu mengeluarkan biaya tempat pelatihan, hardware dan software, dan tenaga trainer yang banyak. Sehingga pada akhirnya solusi tersebut dapat memberikan keunggulan bersaing PT. Intellisys Tripratama melalui layanan pelatihan baru dengan harga yang murah dan berkualitas.

\section{Rumusan Permasalahan}

Beberapa masalah yang ditemui oleh PT Intellisys Tripratama dalam mengembangkan solusi pelatihan online berbasis web adalah: (1) Bagaimana merancang model pelatihan online berbasis web yang sukses sehingga menghasilkan: layanan pelatihan yang murah dan fleksibel, layanan pelatihan yang mudah didapatkan di mana saja dan kapan saja, dan layanan pelatihan dengan materi yang inovatif dan mudah dipelajari; (2) bagaimana memilih dan mengintegrasikan teknologi informasi dan komunikasi yang sesuai untuk membuat solusi pelatihan online berbasis web untuk PT Intellisys Tripratama; (3) bagaimana mengevaluasi bahwa model pelatihan online berbasis web dapat memberikan kemudahan dan layanan yang baik bagi pelanggan dan bisa memberikan keunggulan bersaing bagi PT Intellisys Tripratama.

Tujuan dari penyusunan makalah ini adalah untuk menjawab masalah-masalah yang ditemui oleh PT. Intellisys Tripratama dalam melakukan pengembangan solusi pelatihan online berbasis web. Tujuan secara rinci adalah sebagai berikut: (1) merancang model pelatihan online berbasis web untuk PT Intellisys Tripratama; (2) memilih dan mengintegrasikan teknologi informasi dan komunikasi yang sesuai untuk membuat solusi pelatihan online berbasis web untuk PT Intellisys Tripratama; (3) mengevaluasi bahwa model pelatihan online berbasis web dapat memberikan kemudahan dan layanan pelatihan yang baik bagi pelanggan dan bisa memberikan keunggulan bersaing bagi PT Intellisys Tripratama. Pengembangan model pelatihan online berbasis web diharapkan dapat memberikan manfaat bagi pelanggan dan bagi PT Intellisys Tripratama.

Manfaat bagi Pelanggan PT Intellisys Tripratama, yaitu memberikan pilihan bagi pelanggan untuk memilih jenis layanan pelatihan yang sesuai dengan kebutuhan dan kemampuan pelanggan; memberikan kemudahan bagi pelanggan yang memiliki keterbatasan waktu dan susah untuk mencapai lokasi pelatihan PT Intellisys Tripratama untuk tetap bisa mendapatkan pelayanan pelatihan teknologi informasi yang murah, fleksible, inovatif, mudah dipelajari. Sementara itu, manfaat bagi PT Intellisys Tripratama, yaitu: (1) menghasilkan produk layanan pelatihan baru yang murah, fleksible, inovatif, materi yang mudah dipelajari; (2) memperluas pangsa pasar Intellisys ke berbagai daerah di luar kota Jakarta yang mungkin belum dijangkau oleh kompetitor lainnya; (3) memberikan kemudahan dalam mengembangkan materi pelatihan; (4) dengan pelatihan online berbasis web, Intellisys tidak perlu mengeluarkan biaya tempat pelatihan, infrastruktur pelatihan, dan tenaga pengajar yang banyak; (5) memberikan kemudahan dan pelayanan jasa pelatihan baru yang berkualitas sehingga dapat mendukung keunggulan bersaing PT Intellisys Tripratama.

\section{METODE PENELITIAN}

\section{Kuesioner untuk Staf}

Populasi sebanyak 10 staf pada bisnis unit pelatihan PT. Intellisys Tripratama, maka jumlah minimal sampel penelitian apabila toleransi derajat errornya 0.1 adalah:

$$
\frac{10}{+10\left(0.1^{2}\right)}=9.09090 \approx 9
$$

\section{Kuesioner untuk Pelanggan}

Populasi sebanyak 215 supplier, maka jumlah minimal sampel penelitian apabila toleransi derajat errornya 0.1 adalah:

$$
n=\frac{50}{1+50\left(0.1^{2}\right)}=33.33333 \approx 33
$$

\section{Kajian Teori}

\section{Analisa Situasi Eksternal Perusahaan dengan Porter's Five Competitive Forces}

Dari data yang diperoleh melalui survei di tahapan sebelumnya, dilakukan analisa Porter's Five Competitive Forces (2008). Tujuannya adalah untuk melihat posisi PT Intellisys Tripratama dalam situasi kompetisi dalam industrinya, terkait dengan tekanan dan keuntungan yang ada terhadap perusahaan. Hasil dari analisa ini akan menjadi pola dasar strategi yang akan diterapkan dalam merancang dan mengimplementasikan teknologi informasi yang tepat untuk diterapakan pada perusahaan untuk menghadapi tekanan kompetisi dan sekaligus mendapatkan keuntungan bersaing di dalam industrinya melalui teknologi informasi yang tepat guna

\section{Analisa Situasi Internal dan Eksternal dengan Analisis SWOT}

Dari data yang diperoleh melalui survei di tahapan sebelumnya, dilakukan analisa Strengths, Weaknesses, Opportunities, Threats (SWOT). Tujuannya adalah untuk mengetahui situasi internal dan eksternal pada PT. Intellisys Tripratama, guna mendapatkan formulasi strategi yang tepat. Analisis SWOT ini akan menjadi dasar penyusunan strategi yang akan diterapkan dalam merancang dan mengimplementasikan teknologi informasi yang tepat untuk mendapatkan keunggulan bersaing melalui kekuatan internal perusahaan dan memanfaatkan peluang yang ada. Disamping itu juga dapat untuk segera mengatasi kelemahan perusahaan dengan tujuan untuk mempersiapkan diri dalam memanfaatkan peluang. 


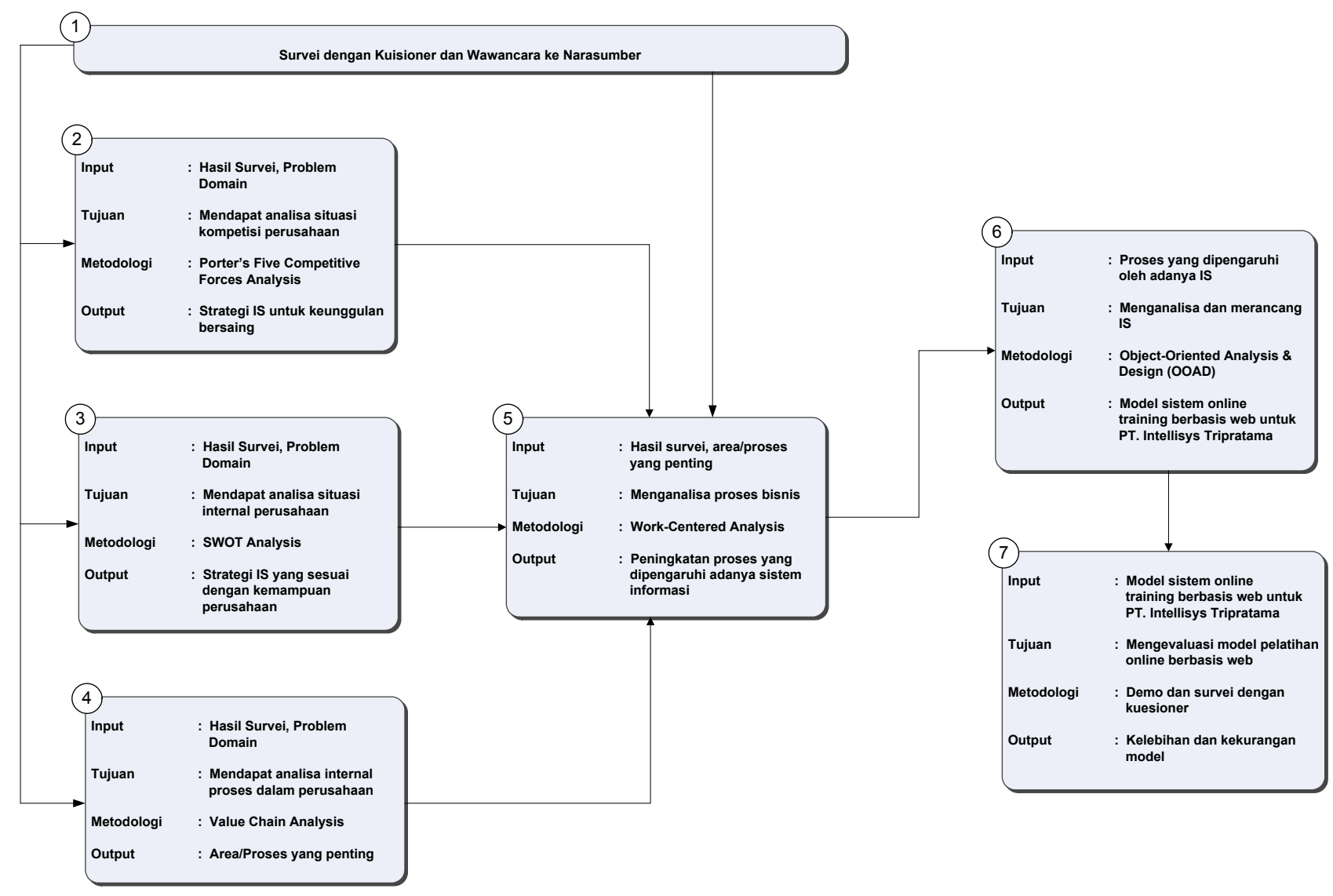

Gambar 1 Survei dengan Narasumber

\section{Analisa Rantai Proses Perusahaan dengan Value Chain Analysis}

Dari data yang diperoleh melalui survei di tahapan sebelumnya, dilakukan analisa proses bisnis pada divisi pelatihan PT. Intellisys dengan menggunakan Value Chain Analysis. Tujuannya adalah untuk mengidentifikasikan serangkaian proses internal pada divisi pelatihan PT. Intellisys dalam rangka memberikan suatu nilai kepada pelanggannya. Melalui hasil analisa ini dapat diperoleh area atau proses bisnis mana yang penting bagi bisnis pelatihan PT Intellisys Tripratama yang ada saat ini.

\section{Analisa Proses Bisnis dengan Work-Centered Analysis (WCA)}

Setelah diperoleh strategi sistem informasi yang cocok untuk keunggulan bersaing perusahaan dan sesuai dengan kemampuan perusahaan ditambah dengan area atau proses yang penting dalam mata rantai proses bisnis pelatihan PT. Intellisys Tripratama, perlu dilakukan analisa proses bisnis menggunakan Work-Centered Analysis. Analisa ini digunakan untuk mengidentifikasi proses bisnis dalam internal organisasi, yang dapat ditingkatkan dalam rangka meningkatkan kepuasan pelanggan sebagai peningkatan keunggulan bersaing dari organisasi tersebut. Hasil analisis ini adalah peningkatan proses bisnis pelatihan dengan menggunakan strategi sistem informasi sebagai sarana peningkatan keunggulan strategis dari PT. Intellisys Tripratama.

\section{Object-Oriented Analysis and Design (OOAD) Menggunakan Unified Modelling Language (UML)}

bisnis terkait dengan permasalahan perusahaan. Selanjutnya pada proses Object-Oriented Analysis and Design (OOAD) akan dilakukan analisa secara lebih rinci terhadap proses bisnis yang akan dilakukan peningkatan sejalan dengan strategi sistem informasi yang digunakan. Dilakukan analisa permasalahan yang dialami oleh setiap stakeholder, mendapatkan informasi kebutuhan yang diinginkan pengguna dan menghasilkan sebuah conceptual model dari informasi yang akan dianalisa. Sehingga kemudian dapat merancang sebuah model yang merupakan rancangan sistem yang menjadi solusi bagi permasalahan yang dialami oleh perusahaan.

Hasil dari tahap ini adalah sebuah model pelatihan online berbasis web yang merupakan solusi teknologi informasi yang sukses dan tepat guna sebagai jawaban dari permasalahan atau peluang yang dimiliki oleh PT Intellisys Tripratama.

\section{Evaluasi Model dengan Melakukan Demo Model dan Survei}

Dari hasil analisa dan perancangan pada tahap sebelumnya sehingga menghasilkan sebuah model pelatihan online berbasis web. Selanjutnya pada proses evaluasi model akan dilakukan demonstrasi penggunaan model pelatihan online berbasis web kepada beberapa pelanggan PT Intellisys Tripratama untuk setiap fungsi pada model. Kemudian meminta pelanggan untuk mengisi kuesioner yang berisi pertanyaan-pertanyaan mengenai model yang telah dijelaskan sebelumnya. Tahapan ini bertujuan untuk memperoleh masukan dari pelanggan terhadap model pelatihan online yang telah dirancang pada tahap sebelumnya, mendapatkan kekurangan dan kelebihan dari model tersebut. 


\section{HASIL DAN PEMBAHASAN}

\section{Hasil Survei Melalui Kuesioner Wawancara}

Hasil survei kepada staf unit bisnis pelatihan \& edukasi sebagai perbandingan dari masukkan pelanggan mengenai kondisi layanan pelatihan dan edukasi PT Intellisys Tripratama adalah sebagai berikut: (1) adanya tekanan bagi penjualan bisnis pelatihan PT Intellisys Tripratama akibat persaingan kualitas dan harga yang semakin ketat dalam bisnis training di Indonesia; (2) ancaman dari pendatang baru relatif tidak berpengaruh bagi bisnis pelatihan PT Intellisys Tripratama; (3) adanya tekanan dari mitra PT Intellisys Tripratama sebagai supplier materi pelatihan; (4) belum ada produk subtitusi yang mempengaruhi bisnis pelatihan PT Intellisys Tripratama; (5) dibutuhkan upaya yang cukup sulit untuk membagikan informasi kepada pelanggan, mengenai pelatihan apa yang dibuka, waktu pelatihan, informasi pengajar dan silabus materi yang akan diajarkan; (6) kesulitan untuk menyesuaikan waktu pelatihan dengan waktu yang diinginkan pelanggan; (7) peran pelatih yang sangat penting dalam menentukan kualitas pelatihan; (8) dibutuhkan investasi yang besar dalam menyediakan infrastruktur pelatihan.

Hasil survei kepada pelanggan unit bisnis Pelatihan \& Edukasi mengenai kondisi layanan pelatihan dan edukasi PT Intellisys Tripratama adalah sebagai berikut: (1) pelanggan menemui kesulitan untuk memperoleh informasi mengenai pelatihan apa yang dibuka, waktu pelatihan, informasi pengajar dan silabus materi yang akan diajarkan; (2) pelanggan menemui kesulitan untuk menentukan pelatihan mana yang sesuai dengan kebutuhan yang diinginkan karena keterbatasan informasi yang diperoleh; (3) kesulitan dalam menyesuaikan waktu dengan jadwal yang disediakan oleh PT Intellisys Tripratamal; (4) bagi pelanggan yang berlokasi diluar Jakarta, mengalami kesulitan untuk mencapai lokasi pelatihan PT Intellisys Tripratama; (5) kualitas pengajar PT Intellisys Tripratama yang tidak merata; (6) keterbatasan waktu pelatihan menjadi kendala bagi sebagian besar pelanggan untuk memahami materi yang cukup banyak.

\section{Analisis Situasi Eksternal Perusahaan dengan Porter's Five Competitive Forces}

\section{Ancaman dari Pendatang Baru (New Entrants)}

Munculnya banyak pendatang baru dengan kecenderungan untuk mendapatkan pangsa pasar dengan strategi membanting harga dengan sangat murah.

\section{Ancaman dari Produk Pengganti (Subtitute Products or Services)}

Produk pengganti yang dimaksudkan disini adalah penyedia pelatihan yang tidak bersertifikasi/non-authorized yang seringkali menurunkan harga secara drastis yang sering kali membingungkan pelanggan yang belum mengerti mengenai perbedaan authorized dan non-authorized. Produk pengganti lainnya adalah pengajar-pengajar lepas/freelance yang bisa menjadi layanan pengganti yang lebih murah, lebih fleksible dari sisi tempat dan waktu karena pasti akan lebih mudah untuk menyesuaikan dengan permintaan tempat dan waktu dari pelanggan.

\section{Tekanan dari Pemasok (Suppliers)}

Intellisys dipersyaratkan untuk memenuhi quota pembelian Microsoft Official Curriculum (MOC) atau materi pelatihan Microsoft, sejumlah yang telah ditentukan oleh Microsoft Indonesia sebagai supplier PT Intellisys Tripratama.

\section{Tekanan dari Pembeli (Buyers)}

Pelanggan akan men-drive judul/jenis pelatihan yang akan diadakan. Disamping tekanan terhadap judul atau jenis pelatihan yang akan diadakan, pelanggan juga memberikan tekanan pada waktu pelatihan yang akan diadakan. Ada beberapa pelanggan yang meminta waktu diluar jam kerja pengajar atau di hari libur, tentu saja perusahaan harus menyanggupi waktu tersebut supaya pelanggan ini tidak beralih ke pesaing lainnya. Tetapi hal ini cukup merepotkan perusahaan karena harus mencari pengajar yang bersedia overtime atau bagi pekerja paruh waktu juga mematok harga yang cukup tinggi untuk waktu khusus seperti ini.

\section{Persaingan dalam Industri yang Sama (Rivalry)}

Adanya persaingan yang ketat dari sisi harga, kualitas pelatihan dan infrastruktur, maupun kualitas materi pelatihan relatif berpengaruh bagi usaha pelatihan PT. Intellisys Tripratama. Pesaing-pesaing utama PT. Intellisys Tripratama pada saat ini adalah penyedia layanan pelatihan bersertifikasi/authorized di Jakarta seperti Inixindo, Iverson, dan ASABA.

\section{Strategi IS Dalam Situasi Kompetisi Perusahaan Untuk Mencapai Keunggulan Bersaing}

Berdasarkan hasil analisa situasi kompetisi perusahaan dan tekanan yang berasal dari berbagai pihak seperti pendatang baru, produk subtitusi, tekanan dari pemasok dan pembeli, hampir dari setiap pihak perusahaan mendapatkan tekanan yang berat oleh karena itu diperlukan sebuah strategi persaingan yang tepat untuk dapat mencapai keunggulan bersaing pada industry pelatihan teknologi informasi. Beberapa strategi yang dapat digunakan adalah: (1) differentiation, dengan memberikan produk pelatihan yang baru dan berkualitas dan dapat menjangkau pangsa pasar yang lebih luas. Penggunaan teknologi informasi secara strategis untuk menghasilkan produk layanan baru, terutama untuk dapat memberikan pelatihan kepada pelanggan yang menginginkan fleksibilitas waktu pelatihan dan pelanggan yang susah mengakses lokasi pelatihan; (2) cost leadership, menghasilkan sebuah produk pelatihan baru dengan biaya yang rendah tetapi tetap berkualitas baik. Hal ini dapat dilakukan PT. Intellisys melalui kemudahan menghasilkan materi pelatihan tanpa harus tergantung kepada pemasok, mudah diakses dari manapun, meminimalkan biaya infrastruktur, pengajar, staf sales dan admin yang cukup besar.

\section{Analisa Kekuatan dan Kelemahan Serta Kondisi Internal dan Eksternal Perusahaan}

\section{Analisis Strengths, Weaknesses, Opportunities, Threats (SWOT)}

Lihat gambar 2.

\section{Strategi IS Yang Sesuai Kemampuan Perusahaan}

Untukmengatasikelemahandanancamandarikompetisi dalam industri pelatihan serta dengan bekal kemampuan dan peluang yang dimiliki PT Intellisys Tripratama, dapat dihasilkan beberapa strategi sistem informasi, yaitu (1) untuk mengatasi komponen biaya materi pelatihan yang tinggi, dan didukung dengan pengajar yang handal, perlu dikembangkan sebuah alat untuk membantu pengajar sebagai penyedia materi 


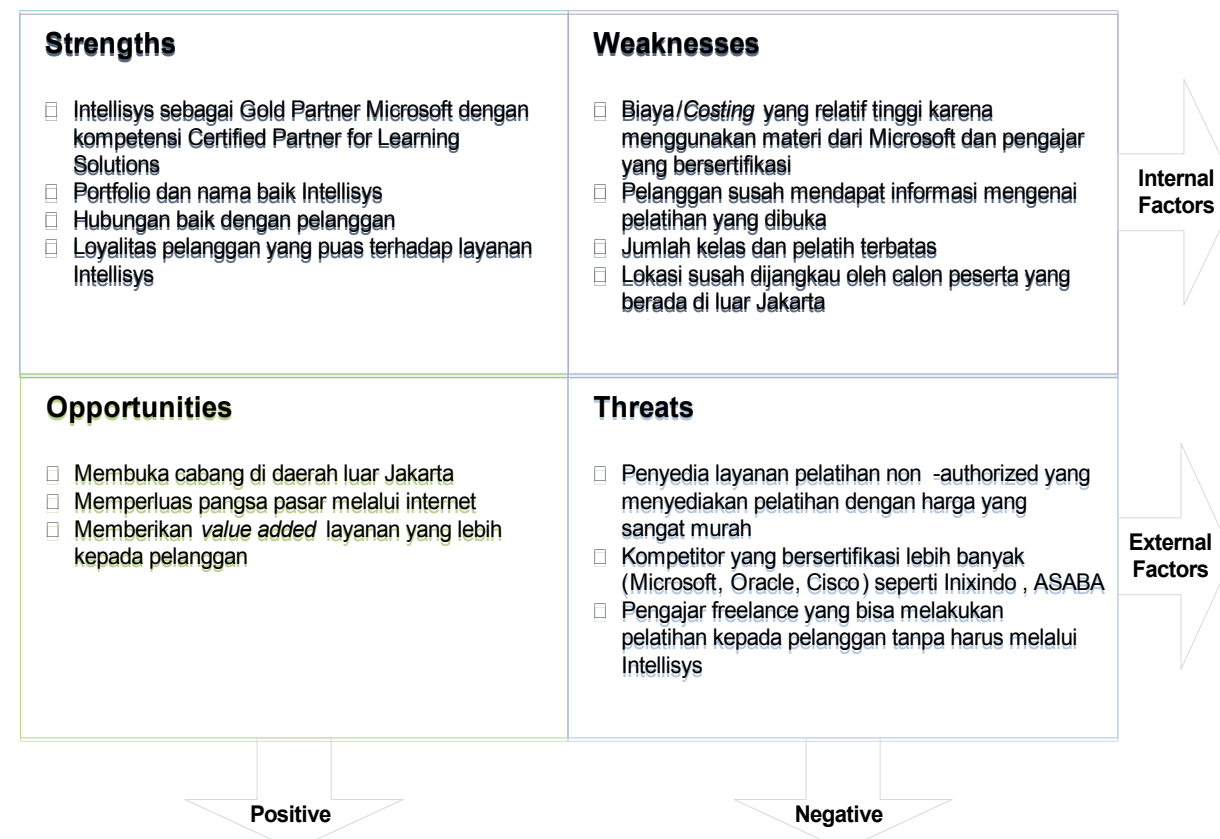

Gambar 2 Analisis SWOT

pelatihan yang dapat menghasilkan materi pelatihan dengan biaya yang murah tetapi berkualitas; (2) agar pelanggan bisa mendapatkan informasi pelatihan dengan mudah, serta dapat memperluas pangsa, dikembangkan sebuah layanan informasi pelatihan melalui web yang dapat diakses dengan mudah dari mana pun dan kapan pun hanya dengan menggunakan internet; (3) untuk mengatasi keterbatasan jumlah kelas dan lokasi pelatihan tradisional yang susah dijangkau oleh calon peserta yang berada di luar Jakarta, didukung dengan nama baik dan portfolio perusahaan di bidang pelatihan teknologi informasi, serta memanfaatkan peluang untuk mendapatkan pangsa pasar di luar Jakarta tanpa harus membuka cabang baru yang tentunya membutuhkan investasi yang cukup besar, dikembangkan sebuah bentuk pelatihan baru yang dilaksanakan secara online melalui web.

\section{Analisa Proses Bisnis Perusahaan}

\section{Analisis Proses Value Chain pada PT. Intellisys}

\section{Tripratama}

Analisa Value Chain Proses diawali dengan analisis value system pada penyedia layanan pelatihan teknologi informasi seperti PT Intellisys Tripratama (lihat gambar 3).

Dimulai dari Microsoft sebagai penyedia materi pelatihan, akan memberikan materi ke dalam rantai nilai PT. Intellisys Tripratama sebagai penyedia layanan pelatihan. Disamping itu juga ada pengajar yang membagikan ilmu dan pengalaman ke dalam rantai nilai penyedia layanan pelatihan. Dalam rantai nilai penyedia layanan pelatihan, nilai lain seperti infrastruktur, konsumsi akan ditambahkan lagi untuk ditujukan kepada peserta pelatihan. Dari peserta pelatihan nilai yang diperoleh dari hasil pelatihan akan diterapkan pada pekerjaan mereka, sehingga perusahaan merasakan peningkatan kualitas kerja dari karyawannya.

\section{Area/Proses yang Penting untuk Dapat Ditingkatkan}

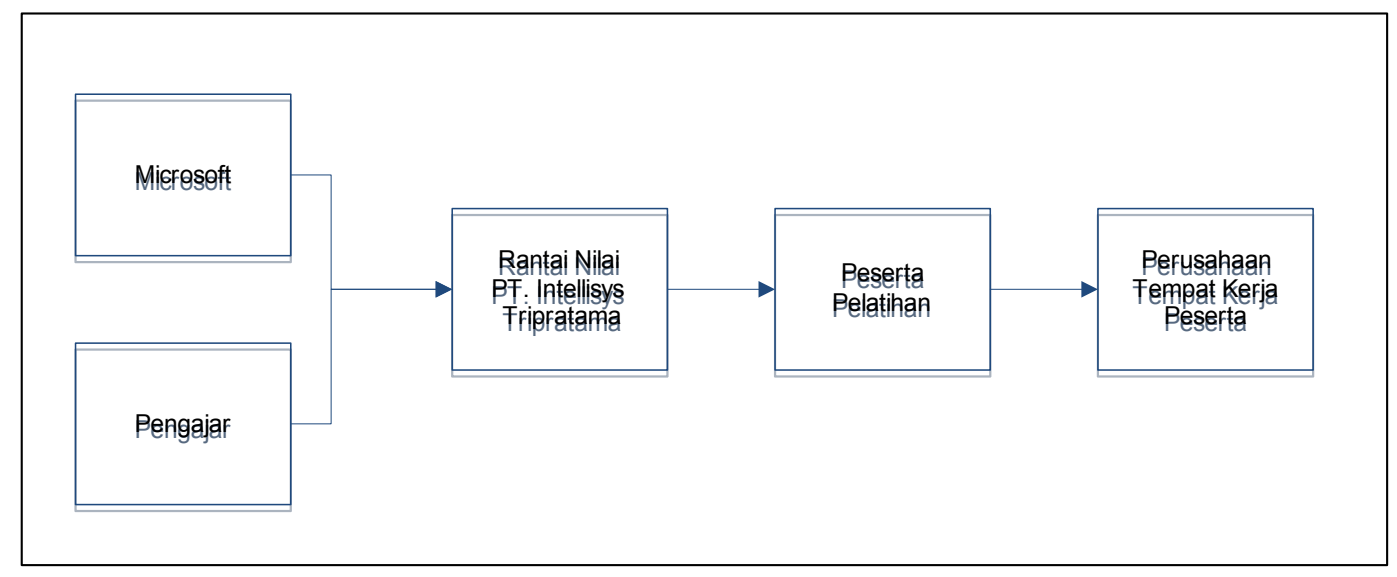

Gambar 3 Analisis proses value chain 
Berikut ini adalah beberapa proses yang berinteraksi tinggi dan proses pelaksanaan pelatihan secara tradisional yang dapat ditingkatkan.

Tabel 1 Aktivitas dan proses yang dapat ditingkatkan

\begin{tabular}{ll}
\hline $\begin{array}{c}\text { Aktivitas dalam } \\
\text { rantai nilai }\end{array}$ & \multicolumn{1}{c}{ Proses Yang Dapat Ditingkatkan } \\
\hline \begin{tabular}{l} 
Pemasaran dan $\begin{array}{l}\text { Penjualan } \\
\text { Paftar Katalog Produk dan Promosi } \\
\text { melalui Web }\end{array}$ \\
\cline { 2 - 2 } Logistik ke dalam
\end{tabular} & $\begin{array}{l}\text { Dukungan Aplikasi Pembuat Materi } \\
\text { Pelatihan }\end{array}$ \\
\cline { 2 - 2 } & Pendaftaran dan Pembayaran secara Online
\end{tabular}

Pelaksanaan Pelatihan secara Online melalui Web

Operasional Pelaksanaan Pelatihan Offline bagi peserta yang tidak memiliki koneksi internet pribadi

Logistik Keluar $\quad \begin{aligned} & \text { Pencetakan Sertifikat yang dihasilkan oleh } \\ & \text { sistem }\end{aligned}$

\section{Analisa Proses Bisnis dengan Work-Centered Analysis (WCA)}

Hasil Peningkatan Proses yang Potensial dapat dilihat pada gambar 4:

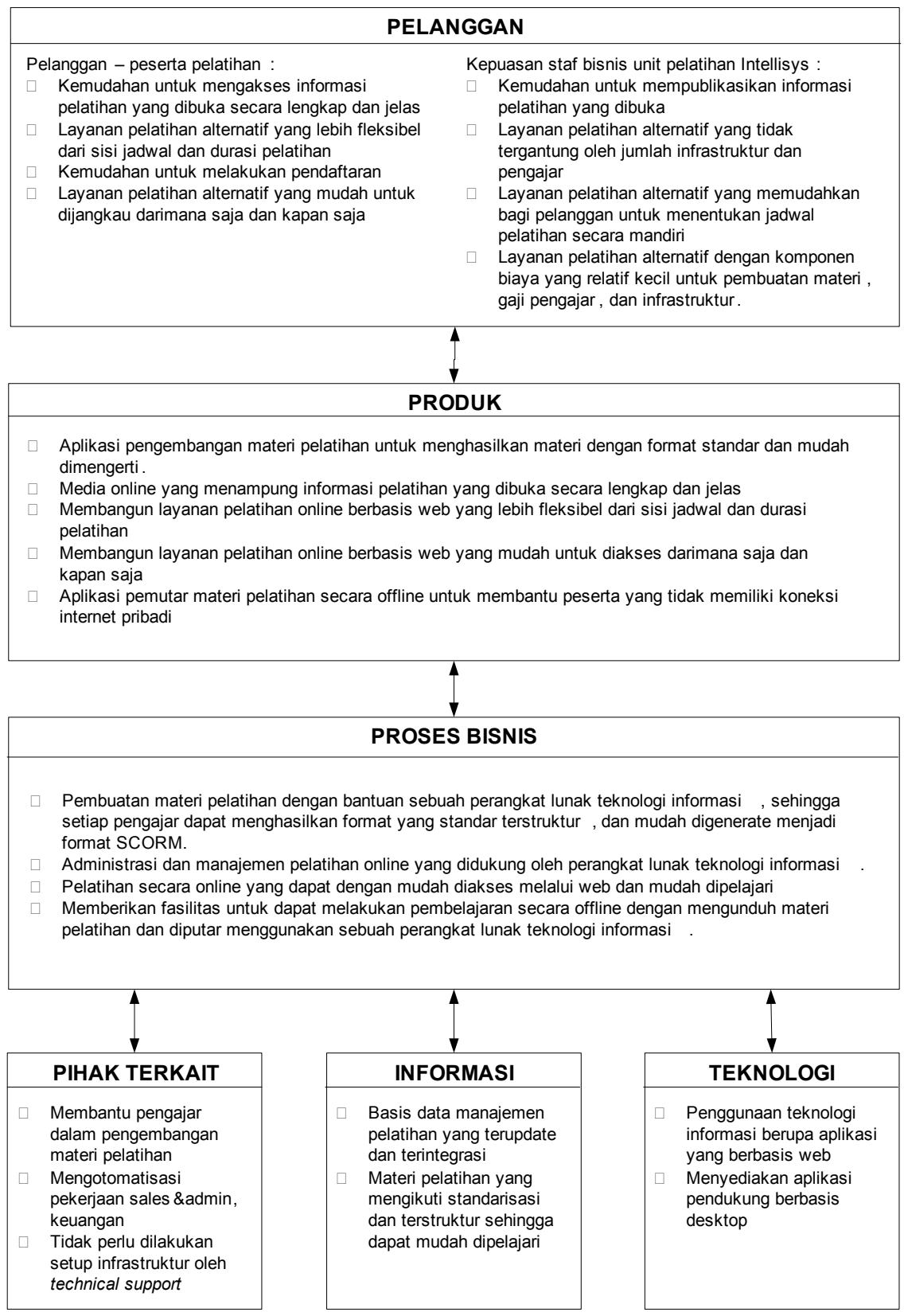

Gambar 4 Proses bisnis dengan work-centered analysis 


\section{Object-Oriented Analysis dan Design}

(OOAD) Menggunakan Unified Modelling

Language (UML)

\section{Analisis Business Use Case untuk Sistem Pelatihan Tradisional}

Berikut ini (Gambar 5) adalah gambar sistem level bisnis use case yang berkaitan dengan proses pelaksanaan pelatihan tradisional.

Detail proses dan Sub Proses Pelatihan Tradisional dapat dilihat pada tabel 2 sebagai berikut:

Tabel 2 Proses dan sub proses pelatihan tradisional

\begin{tabular}{ll}
\hline \multicolumn{1}{c}{ Proses } & \multicolumn{1}{c}{ Sub Proses } \\
\hline $\begin{array}{l}\text { Pelayanan Informasi } \\
\text { Pelatihan }\end{array}$ & Pelayanan Informasi \\
Pelatihan \\
Pendaftaran Peserta & Pendaftaran atas \\
Pelatihan & pelatihan yang dipilih \\
\hline
\end{tabular}

Persiapan infrastruktur

Persiapan materi

Persiapan Pelatihan

pelatihan

Persiapan pengajar

Penyampaian materi pelatihan

Pembahasan studi kasus

Pelaksanaan Pelatihan

Tanya jawab

Pengerjaan Latihan

Pengujian Akhir

Pelatihan

Pengisian formulir

evaluasi pelaksanaan

pelatihan

Pembayaran biaya pelatihan

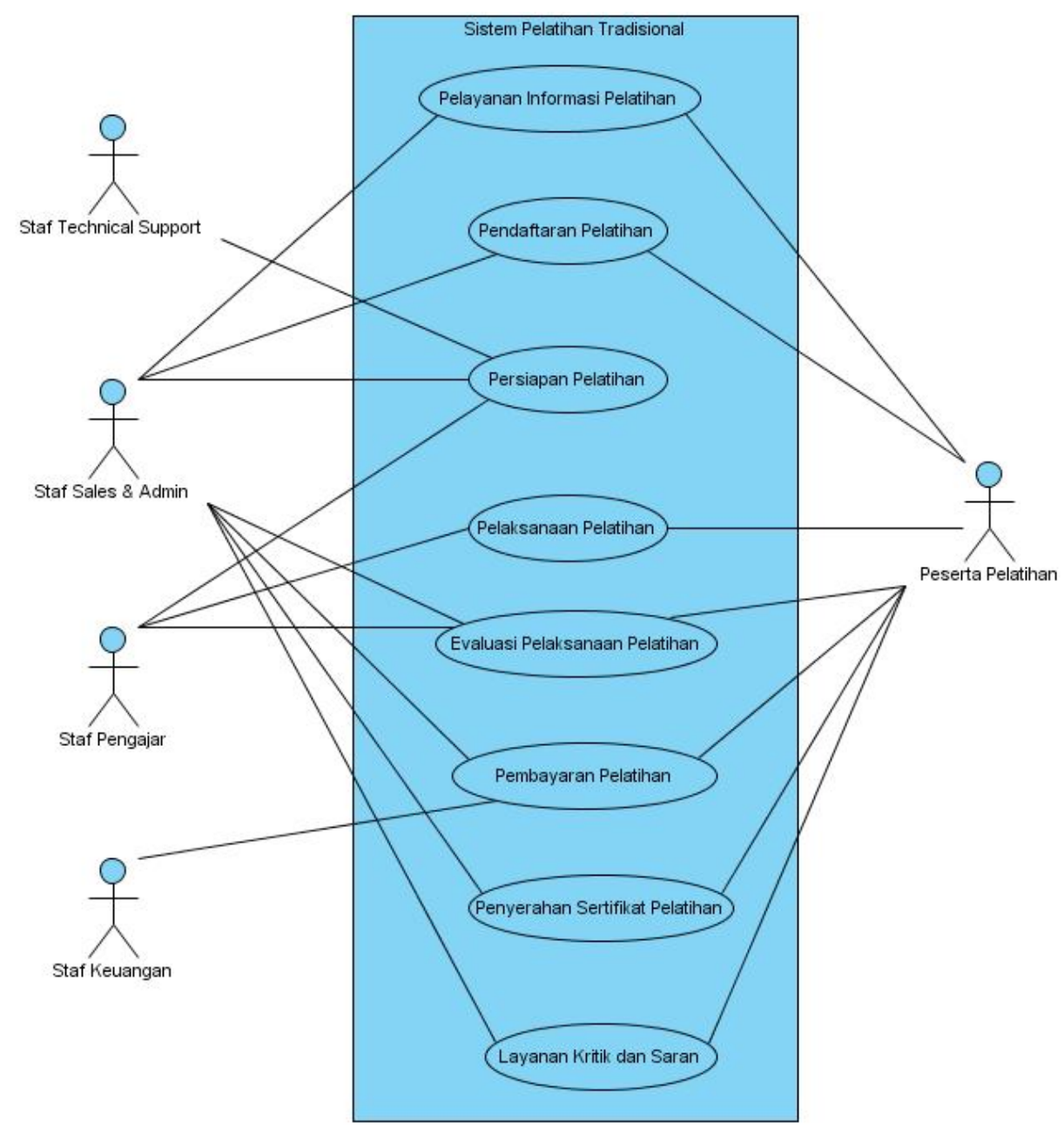

Gambar 5 Sistem level bisnis use case 


\begin{tabular}{ll}
\hline $\begin{array}{l}\text { Penyerahan Sertifikat } \\
\text { Pelatihan }\end{array}$ & $\begin{array}{l}\text { Penyerahan sertifikat } \\
\text { pelatihan }\end{array}$ \\
\hline Pelayanan Kritik dan Saran & $\begin{array}{l}\text { Layanan Kritik dan } \\
\text { Saran }\end{array}$ \\
\hline
\end{tabular}

\section{Analisis Business Use Case untuk Sistem Pelatihan Online berbasis Web}

Lihat gambar 6, 7, 8 sebagai berikut:

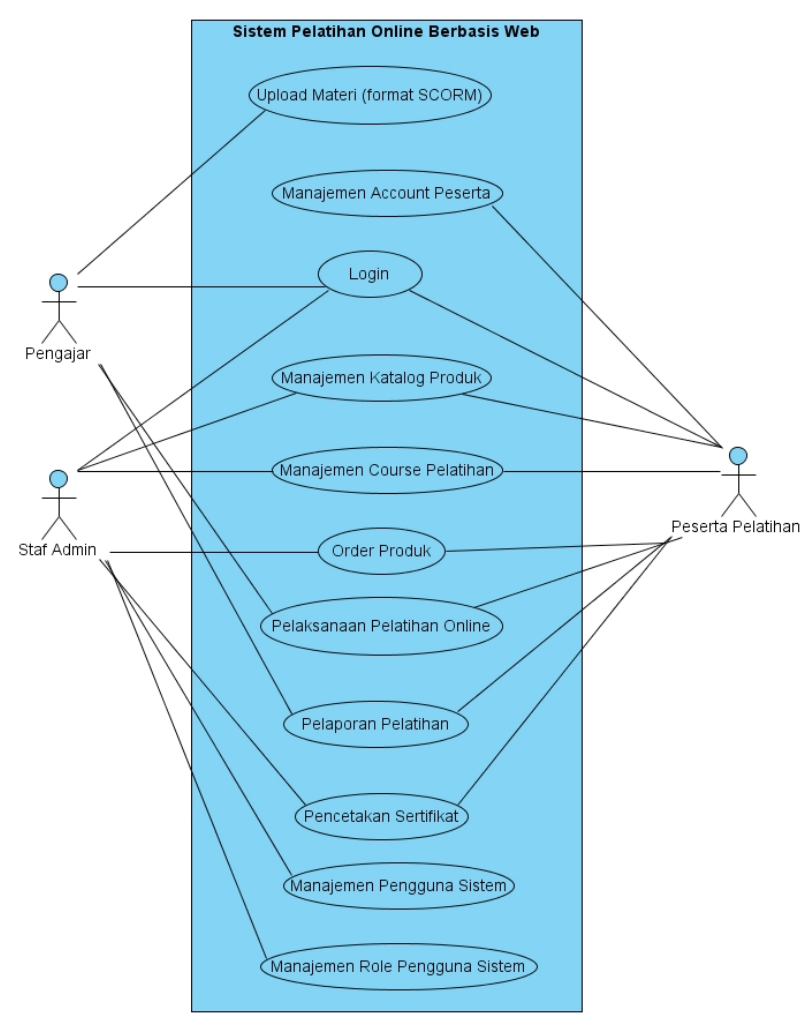

Gambar 7 System Level Use Case Pelatihan Online berbasis Web

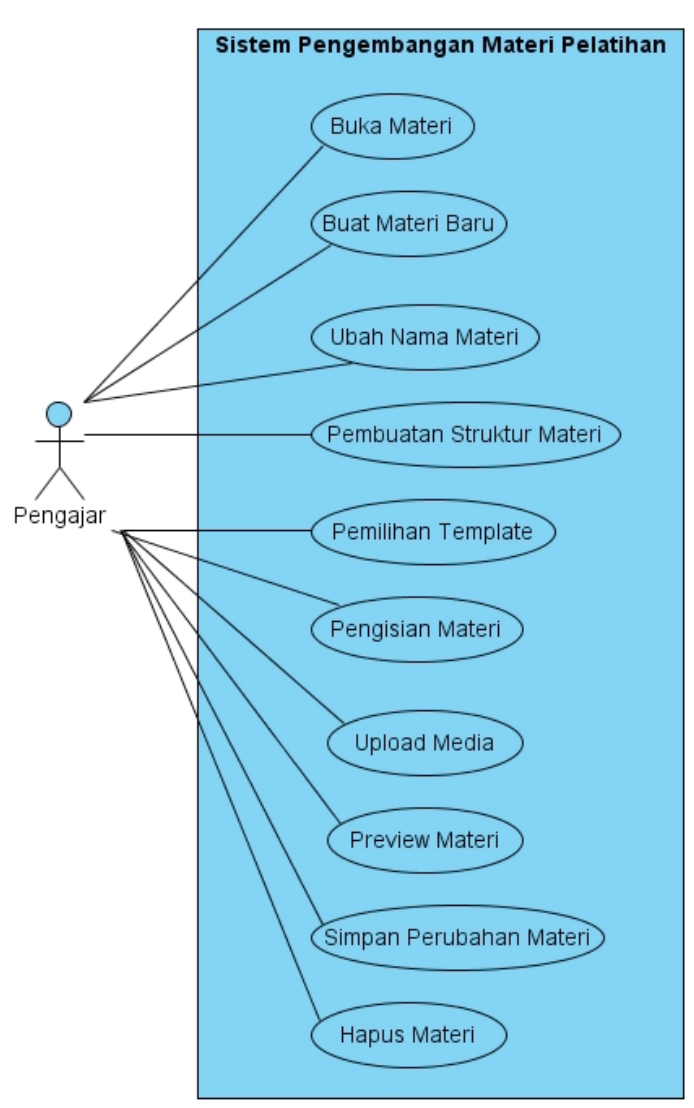

Gambar 6 System Level Use Case Pengembangan Materi Pelatihan

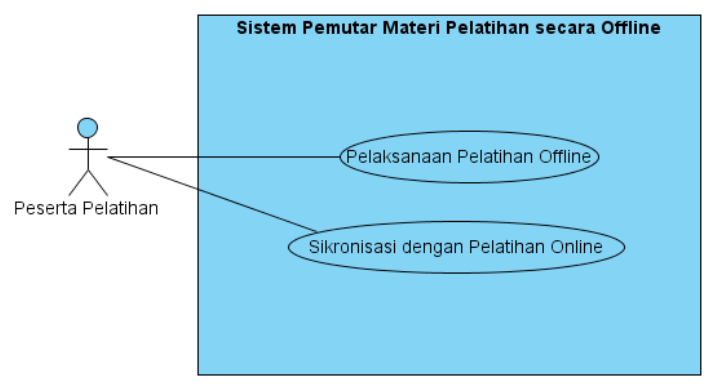

Gambar 8 System Level Use Case Pemutar Materi Pelatihan secara Offline

Tabel 3 Fungsi-fungsi pada aplikasi pengembangan materi pelatihan

\begin{tabular}{ll}
\hline \multicolumn{1}{c}{ Proses Baru } & \multicolumn{1}{c}{ Sub Proses Baru } \\
\hline Buka Materi & Buka materi \\
\hline Buat Materi Baru & Buat materi baru \\
\hline Ubah Nama Materi & Ubah nama materi \\
\hline \multirow{5}{*}{ Pembuatan Struktur Materi } & Tambah module \\
\cline { 2 - 2 } & Ubah judul module \\
\cline { 2 - 2 } & Hapus module \\
\cline { 2 - 2 } & Tambah lesson \\
\cline { 2 - 2 } & Hapud lesson \\
\cline { 2 - 2 } & Tambah topic \\
\cline { 2 - 2 } & Ubah judul topic \\
\cline { 2 - 2 } & Hapus topic \\
\hline
\end{tabular}




\begin{tabular}{ll}
\hline \multirow{2}{*}{ Pemilihan Template } & Pemilihan template \\
\cline { 2 - 2 } Pengisian Materi & Ubah template \\
\hline & Isi materi \\
\cline { 2 - 2 } & Ubah isi materi \\
\hline Preview Materi & Preview materi \\
\hline Simpan Perubahan Materi & Simpan perubahan materi \\
\hline Hapus Materi & Hapus materi \\
\hline
\end{tabular}

\begin{tabular}{|c|c|}
\hline \multirow{3}{*}{$\begin{array}{l}\text { Manajemen Course } \\
\text { Pelatihan }\end{array}$} & $\begin{array}{l}\text { Lihat daftar pelatihan yang } \\
\text { sedang diikuti }\end{array}$ \\
\hline & $\begin{array}{l}\text { Lihat daftar pelatihan yang } \\
\text { ingin diikuti }\end{array}$ \\
\hline & $\begin{array}{l}\text { Lihat daftar pelatihan yang } \\
\text { telah selesai }\end{array}$ \\
\hline \multirow{3}{*}{ Order Produk } & $\begin{array}{l}\text { Tambah produk ke keranjang } \\
\text { belanja }\end{array}$ \\
\hline & Submit pembelian \\
\hline & $\begin{array}{l}\text { Pembayaran produk } \\
\text { pelatihan }\end{array}$ \\
\hline \multirow{13}{*}{$\begin{array}{l}\text { Pelaksanaan } \\
\text { Pelatihan Online }\end{array}$} & Masuk sesi pelatihan \\
\hline & Pembelajaran materi \\
\hline & Demonstrasi materi \\
\hline & Pengerjaan latihan pribadi \\
\hline & Pengujian akhir pelatihan \\
\hline & Keluar sesi pelatihan \\
\hline & Tanya jawab melalui chat \\
\hline & Kirim pesan chat \\
\hline & Balas pesan chat \\
\hline & Tanya jawab melalui pesan \\
\hline & Kirim pesan \\
\hline & Balas pesan \\
\hline & Lihat histori tanya jawab \\
\hline \multirow{2}{*}{ Pelaporan Pelatihan } & $\begin{array}{l}\text { Laporan progress pelatihan } \\
\text { yang sedang diikuti }\end{array}$ \\
\hline & $\begin{array}{l}\text { Laporan hasil pelatihan yang } \\
\text { telah diikuti }\end{array}$ \\
\hline
\end{tabular}

\begin{tabular}{|c|c|}
\hline Proses Baru & Sub Proses Baru \\
\hline \multirow{3}{*}{$\begin{array}{l}\text { Upload Materi } \\
\text { (format SCORM) }\end{array}$} & Lihat daftar produk pelatihan \\
\hline & $\begin{array}{l}\text { Upload materi pelatihan } \\
\text { (format SCORM) }\end{array}$ \\
\hline & Hapus materi pelatihan \\
\hline \multirow{2}{*}{$\begin{array}{l}\text { Manajemen Account } \\
\text { Peserta }\end{array}$} & Buat account baru \\
\hline & Ubah account baru \\
\hline \multirow{3}{*}{ Login } & Login peserta \\
\hline & Login pengajar \\
\hline & Login admin \\
\hline \multirow{4}{*}{$\begin{array}{l}\text { Manajemen Katalog } \\
\text { Produk }\end{array}$} & Tambah data produk \\
\hline & Pencarian data produk \\
\hline & Ubah data produk \\
\hline & Hapus data produk \\
\hline
\end{tabular}

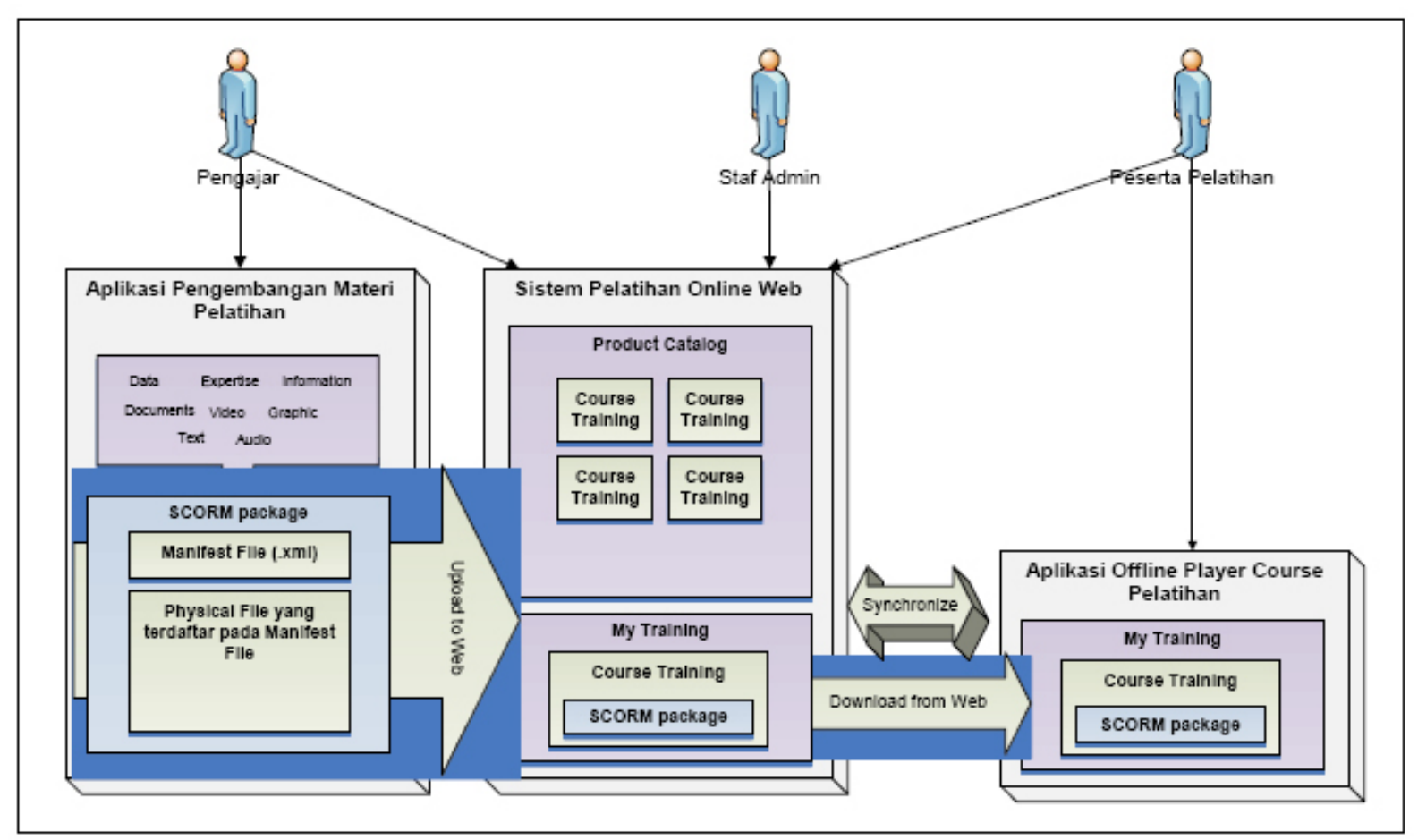

Gambar 9 Rancangan Model Konseptual dari Sistem Pelatihan Online Berbasis Web dan Aplikasi Pendukung Lainnya 


\begin{tabular}{|c|c|}
\hline \multirow{3}{*}{ Pencetakan Sertifikat } & $\begin{array}{l}\text { Daftar pelatihan yang telah } \\
\text { selesai }\end{array}$ \\
\hline & Preview hasil cetak \\
\hline & Cetak sertifikat \\
\hline \multirow{6}{*}{$\begin{array}{l}\text { Manajemen } \\
\text { Pengguna Sistem }\end{array}$} & Buat pengguna baru \\
\hline & Lihat data pengguna \\
\hline & Ubah data pengguna \\
\hline & Hapus pengguna \\
\hline & Tambah role pengguna \\
\hline & Hapus role pengguna \\
\hline \multirow{4}{*}{$\begin{array}{l}\text { Manajemen Role } \\
\text { Pengguna Sistem }\end{array}$} & Buat role \\
\hline & Hapus role \\
\hline & Tambah hak akses role \\
\hline & Hapus hak akses role \\
\hline
\end{tabular}

Tabel 5 Fungsi-fungsi pada Aplikasi Pemutar Materi Pelatihan secara Offline

\begin{tabular}{ll}
\hline \multicolumn{1}{c}{ Proses Baru } & \multicolumn{1}{c}{ Sub Proses Baru } \\
\hline \multirow{4}{*}{$\begin{array}{l}\text { Pelaksanaan Pelatihan } \\
\text { Offline }\end{array}$} & Masuk sesi pelatihan offline \\
\cline { 2 - 2 } & Pembelajaran materi \\
\cline { 2 - 2 } & Demonstrasi materi \\
\cline { 2 - 2 } $\begin{array}{l}\text { Pengerjaan latihan pribadi } \\
\text { Pelatihan Online }\end{array}$ & Keluar sesi pelatihan online \\
\hline
\end{tabular}

\section{Evaluasi Model Dengan Melakukan Demo Model dan Survei}

Tabel 6 Analisis hasil evaluasi model pelatihan berbasis web

\begin{tabular}{ll}
\multicolumn{1}{c}{$\begin{array}{c}\text { Model Sistem Pelatihan } \\
\text { Online Berbasis Web }\end{array}$} & $\begin{array}{c}\text { Keunggulan Bersaing } \\
\text { Yang Diperoleh }\end{array}$ \\
\hline $\begin{array}{l}\text { Memberi pelanggan sebuah } \\
\text { layanan pelatihan yang } \\
\text { murah dan fleksibel }\end{array}$ & $\begin{array}{l}\text { Produk dan layanan yang } \\
\text { murah dan perkualitas }\end{array}$ \\
\hline $\begin{array}{l}\text { Memberi pelanggan sebuah } \\
\text { layanan pelatihan yang } \\
\text { mudah didapatkan dimana } \\
\text { saja dan kapan saja }\end{array}$ & $\begin{array}{l}\text { Produk dan layanan yang } \\
\text { murah dan perkualitas }\end{array}$ \\
\hline $\begin{array}{l}\text { Memberi pelanggan sebuah } \\
\text { layanan pelatihan dengan } \\
\text { materi yang inovatif dan } \\
\text { mudah dipelajari }\end{array}$ & $\begin{array}{l}\text { Produk dan layanan yang } \\
\text { murah dan perkualitas }\end{array}$ \\
\hline $\begin{array}{l}\text { Memberikan pilihan bagi } \\
\text { pelanggan untuk memilih } \\
\text { jenis layanan pelatihan yang } \\
\text { sesuai dengan kebutuhan dan } \\
\text { kemampuan pelanggan }\end{array}$ & $\begin{array}{l}\text { Palue Added bagi produk } \\
\text { tradisional }\end{array}$ \\
\hline
\end{tabular}




\section{Saran}

Perlunya dilakukan survei atau studi lebih lanjut mengenai kebutuhan permintaan layanan pelatihan online bagi pengguna jasa pelatihan di Indonesia. Pengembangan model pelatihan online berbasis dengan penambahan fungsi, yaitu: (1) media forum, blog, atau social networking dimana banyak peserta bisa saling berkomunikasi, berkolaborasi, sharing, dan berdiskusi untuk menumbuhkan knowledge bersama; (2) media tanya jawab yang lebih interaktif seperti virtual meeting atau web conferencing. Melakukan evaluasi lebih lanjut dari sisi ekonomis, investasi yang dikeluarkan terhadap hasil yang diperoleh. Melakukan perhitungan investasi yang harus dikeluarkan untuk mengembangkan model pelatihan online berbasis web menjadi sebuah sistem pelatihan online berbasis web.

\section{DAFTAR PUSTAKA}

Alter, S., Robinson, M. (1996). Information Systems, a Management Perspective. Irwin/McGraw-Hill, Boston - Massachussets.

Booch, G., et. al. (2007). Object-oriented analysis and design with applications. Westford, Massachussets: Pearson Education Inc.

Fallon, C., \& Brown, S. (2003). E-learning standards: a guide to purchasing, developing, and deploying standards conformant e-learning. Florida, United States of America: St. Lucie Press.

Hitt, M. A., et. al. (2008). Strategic management competitiveness and globalization: concept \& cases. Mason, United States of America: South-Western Cengage Learning.

Pope, C. (2001). Implementing e-learning solutions. United States of America: American Society for Training \& Development.

Porter, M. E. (2008). On competition. Boston, United States of America: Harvard Business School Publishing Corporation.

Rosenberg, M. J. (2001). Buiding successful online learning in your organization: strategies for delivering knowledge in the digital age. New York, United States of America: McGraw-Hill.

Umar, H. (2000). Riset Pemasaran dan Perilaku Konsumen. Jakarta: Gramedia Pustaka Utama.

Ward, J., \& Peppard, J. (2002). Strategic planning for information systems. Chicester, England: John Willy \& Sons Ltd.

Weller, M. (2002). Delivering learning on the net. New York, United States of America: Kogan Page Ltd. 